\title{
Regional Differences in Phosphorus Budgets in Intensive Soybean Agriculture
}

\author{
SHELBY H. RISKIN, STEPHEN PORDER, MEAGAN E. SCHIPANSKI, ELENA M. BENNETT, AND CHRISTOPHER NEILL
}

Fertilizer-intensive agriculture has been integral to increasing food production over the past half century but has been accompanied by environmental costs. We use case studies of phosphorus fertilizer use in the world's most productive soybean-growing regions, Iowa (United States), Mato Grosso (Brazil), and Buenos Aires (Argentina), to examine influences of management and soil type on agriculture's most prevalent phosphorusrelated environmental consequences: eutrophication and consumption of Earth's finite phosphorus reserves. With increasing phosphorus inputs, achieving high yields on tropical soils with high phosphorus-binding capacity is becoming more common. This system has low eutrophication risks but increases demands on phosphorus supplies. In contrast, production in traditional breadbaskets, on soils with lower phosphorus-binding capacities, is being sustained with decreasing phosphorus inputs. However, in these regions, historical overuse of phosphorus may mean continued eutrophication risk even as pressures on phosphorus reserves diminish. We focus here on soybean production but illustrate how achieving sustainable agriculture involves an intricate optimization of local, regional, and global considerations.

Keywords: phosphorus, fertilizer, soybean, agriculture, environment

ntensive inputs of fertilizer to large-scale, single-crop agriculture have enabled food production to increase to more than double in the past 40 years (Tilman et al. 2001, FAO 2009) and have played a central role in allowing global crop production to keep pace with the world's increasing demands for food, fiber, biofuels, and feed. However, highinput agriculture comes with environmental costs, including the eutrophication of surface waters, increased emissions of greenhouse gas, and reductions in air quality. For example, throughout intensively farmed regions of North America (Turner and Rabalais 2003, Jacobson et al. 2011), Europe (Billen et al. 2007), and eastern China (Daoji and Daler 2004), water quality declines associated with eutrophication are common. However, the environmental costs of intensively managed agriculture are not monolithic and vary in different biophysical settings, even where the same crops are grown and the same yields are achieved. In order to assess the relative costs and benefits of intensive agriculture, society must weigh both local and global environmental consequences and assess their relative importance.

To illustrate this point, we present a case study of phosphorus application and losses in intensive soybean agriculture across three states in the world's most important soybean growing regions: Iowa (in the United States), Mato Grosso (in Brazil) and the Province of Buenos Aires (in Argentina). Soybeans are the world's most important source of protein feed and are the second largest source of vegetable oil (USDA 2010a). Over the last 40 years, global oil-crop production, of which soybeans make up about $60 \%$, has quadrupled (USDA 2011). The United States, Brazil, and Argentina together produce $80 \%$ of the global soybean crop (http://quickstats.nass. usda.gov). The three states we focus on here make substantial contributions to national soybean harvests and have very similar crop yields (table 1), despite these crops occurring on different soil types, with different levels of total soil phosphorus and soil phosphorus-binding capacity and despite different historical and current management practices. We focus here not on the differences in yield (which are small) but on how the biophysical setting and management history may influence two of the most pressing environmental concerns associated with phosphorus fertilization: eutrophication (Turner and Rabalais 2003, Rockström et al. 2009, Carpenter and Bennett 2011) and the consumption of the Earth's phosphorus supplies (Childers et al. 2011, Villalba et al. 2008).

The use of phosphorus in fertilizer presents a unique and global environmental concern, because phosphorus is mined from finite reserves (unlike nitrogen, which can be fixed from the atmosphere), is without a substitute (unlike fossil fuels), and is used almost exclusively for agriculture (Smil 2000). Phosphorus additions were critical for increasing soybean yields, as they were for other crops, in the latter half of the twentieth century (Tilman et al. 2001), and soybean production accounts for $7 \%$ of annual global phosphorus fertilizer consumption (Heffer 2009). Increased phosphorus

BioScience 63: 49-54. ISSN 0006-3568, electronic ISSN 1525-3244. @ 2013 by American Institute of Biological Sciences. All rights reserved. Request permission to photocopy or reproduce article content at the University of California Press's Rights and Permissions Web site at www.ucpressjournals.com/ reprintinfo.asp. doi:10.1525/bio.2013.63.1.10 


\begin{tabular}{|c|c|c|c|c|c|c|}
\hline Location & $\begin{array}{l}\text { Dominant soil } \\
\text { orders }\end{array}$ & $\begin{array}{l}\text { Area of planted } \\
\text { soybeans (in millions } \\
\text { of hectares) }\end{array}$ & $\begin{array}{l}\text { Percentage of } \\
\text { location planted } \\
\text { with soybeans }\end{array}$ & $\begin{array}{l}\text { Yield (in tons } \\
\text { per hectare) }\end{array}$ & $\begin{array}{l}\text { Percentage of } \\
\text { the national } \\
\text { harvest }\end{array}$ & $\begin{array}{l}\text { Percentage } \\
\text { of the world } \\
\text { harvest }\end{array}$ \\
\hline lowa $a^{a, b}$ & Mollisol, Alfisol & 4.0 & 27 & 3.4 & 15 & 5.2 \\
\hline Mato Grosso ${ }^{b, c}$ & Oxisol, Ultisol & 5.8 & 6.5 & 3.1 & 30 & 6.9 \\
\hline Buenos Aires & Mollisol, Alfisol & 5.7 & 18 & 3.0 & 32 & 6.5 \\
\hline
\end{tabular}

application has led to widespread eutrophication of surface waters (Turner and Rabalais 2003, Rockström et al. 2009, Carpenter and Bennett 2011) and to recent concerns over both the depletion of finite global phosphorus reserves and the geopolitical implications of the concentration of those reserves in only a handful of countries (Villalba et al.2008, Childers et al. 2011). At the same time, underuse of phosphorus can reduce soil fertility, potentially affecting future crop yields and food production.

We expected that regional differences in soil phosphorus availability would influence phosphorus fertilization strategies and the environmental implications of phosphorus surpluses or deficits (i.e., the balance between phosphorus inputs and phosphorus exported in crops). Soil phosphorus availability is a function of not only the total concentration of phosphorus in soil but also the fraction of total phosphorus readily available to plants. The total phosphorus content in soil prior to agricultural management is related to several factors, but on average, older soil or soil in humid tropical climates tends to have both less total phosphorus and a lower fraction of phosphorus in plant-available form compared with younger soil in more temperate climates (Sanchez 1976, Walker and Syers 1976, Zhang et al. 2005). Iron and aluminum oxides in strongly weathered soil types (generally, Ultisols and Oxisols) have a high capacity for binding fertilizer phosphorus in forms that are not immediately available for uptake by plants, so these soil types require more phosphorus fertilizer inputs to achieve yields similar to those in soil types with a lower phosphorus-binding capacity (Sanchez 1976).

We used national- and state-level data on soil types, fertilizer use, and crop yields to compare the environmental constraints on and the potential environmental consequences of intensive agriculture in Iowa, Mato Grosso, and the Province of Buenos Aires. Because each of these states commonly rotates crops, we included the crops in rotation with soybeans in our comparison. We looked at inputs and outputs for soybeans and the most commonly rotated crops, including corn in Iowa and Mato Grosso (Padgitt 1994, Galford et al. 2010) and corn and wheat in Buenos Aires (see the supplemental material, available online at http:// dx.doi.org/10.1525/bio.2013.63.1.10; García 2001). Although all three regions produce comparable soybean yields (table 1), differences in soil phosphorus stocks and soil phosphorusbinding capacity, as well as in land-use histories have led to divergent strategies for current phosphorus fertilizer use among the regions (table 2, figure 1).

\section{Mato Grosso}

Soil with high phosphorus-binding capacity underlies 35\% of the area in intensive agriculture in Mato Grosso (Ahamed et al. 2006). To maintain high yields from these soil types, phosphorus additions to soybean crops in Mato Grosso are large, averaging 35 kilograms (kg) of phosphorus per hectare (ha) per year (see the supplemental material). However, the high phosphorus-binding capacity of soil reduces the risk of leaching of this surplus phosphorus (Hansen et al. 2002).

Expansion of soybean production in Mato Grosso is a relatively recent phenomenon. Although deforestation and land clearing for agriculture in Mato Grosso was historically driven by slash-and-burn practices for cattle ranching (Morton et al. 2006, Nepstad et al. 2006), the 1980s saw the introduction of soybean varieties that thrive in the humid Amazonian climate (Nepstad et al. 2006). Cropland is most commonly single-cropped soybeans or double-cropped soybeans and corn (Galford et al. 2010). Including phosphorus inputs to both corn and soybeans, the high phosphorus inputs 


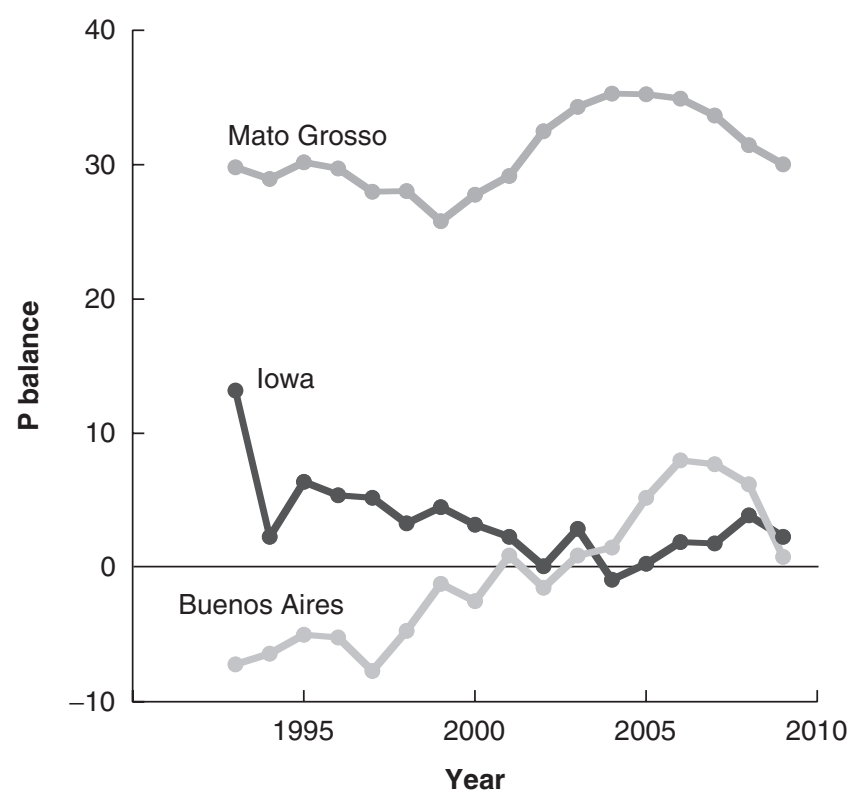

Figure 1. Similar yields but different inputs produced disparate phosphorus $(P)$ balances (in kilograms of $P$ per hectare per year) for Mato Grosso, in Brazil; Iowa, in the United States; and the Province of Buenos Aires, in Argentina, between 1993 and 2009. P balances calculated for land in soybean production and include all major rotated crops for each region.

used to achieve high yields on Mato Grosso farms have added approximately $31 \mathrm{~kg}$ of phosphorus per ha per year more than they have removed over the past 15 years (figure 1; also see the supplemental material). These phosphorus balances became more positive with time, increasing between 1993 and 2009. Both yields and fertilizer inputs increased (see the supplemental material). Despite this surplus, vertical phosphorus leaching through the soil profile in these soils with high phosphorus-binding capacity is unlikely (Hansen et al. 2002). In addition to soil with high phosphorus-binding capacity, the landscape is flat in much of the region; soil infiltration is rapid; and overland flow is minimal, even during intense storms, which reduces the risk of particulate phosphorus loss through water erosion (Hayhoe et al. 2011). Given this combination of characteristics, it is likely that that local risk of eutrophication in this landscape is lower than might be expected given the large phosphorus surpluses.

\section{lowa}

Soybean cultivation has a long history in Iowa, with the first production records dating from 1924 (USDA 2011). In stark contrast to Mato Grosso, Iowa has no soils with high phosphorus-binding capacity and is dominated by Mollisols and Alfisols-generally fertile soil types with higher levels of total and available phosphorus than the highly weathered Oxisols and Ultisols (table 2). In Iowa, farmers applied an average of $25 \mathrm{~kg}$ of phosphorus per ha per year to soybean fields between 1982 and 2010 (USDA 2010b; also see the supplemental material). Much land area planted in soybean, however, is not fertilized annually (Padgitt 1994, Dabekow and Huang 2006). Instead, rotated crops (most commonly corn) receive phosphorus fertilizer, and soybeans are planted the following growing season with no additional inputs (Padgitt 1994, Dabekow and Huang 2006). Manure inputs are also important in Iowa (Ribaudo and Gollehon 2006). Fields near livestock facilities often receive disproportionately high phosphorus inputs compared with other fields (Whalen and Chang 2001). Including the percentage of fields receiving fertilizer, inputs to corn crops, and manure inputs, the area in soybean cultivation received, on average, approximately $3 \mathrm{~kg}$ of phosphorus per ha per year more than was removed between 1993 and 2009 (see the supplemental material).

In our balances, we do not consider spatial variability, and there are undoubtedly areas with larger phosphorus surpluses and others with phosphorus deficits. For example, we would expect fields receiving disproportionately high annual manure inputs to have accumulated larger phosphorus surpluses than would have fields in rotation with corn that were treated only with inorganic phosphorus fertilizers (Whalen and Chang 2001). In addition, the phosphorus balance in Iowa for the area in soybean production decreased with time between 1982 and 2009 (see the supplemental material). In a recent analysis for the Mississippi Basin, however, neither net phosphorus nor manure inputs were shown to correlate with levels of phosphorus watershed export (Jacobson et al. 2011). Instead, at the county level, both the percentage of land in crops and fertilizer phosphorus inputs were correlated with phosphorus export, even those with negative phosphorus balances (i.e., phosphorus deficits; Jacobson et al. 2011). This may be because agricultural practices such as tilling increase phosphorus losses to surface waters, and it may also be a function of land-use history (Jacobson et al. 2011). Decades of high phosphorus fertilizer inputs to soil types that are not efficient at binding phosphorus, combined with particulate and dissolved phosphorus fluxes in overland flow and tile drainage (Hansen et al. 2002), make these soils particularly susceptible to phosphorus losses.

Eutrophication associated with fertilized agriculture in Iowa is a major environmental concern. Iowa, along with 41 other states in the United States, has a phosphorus index as part of their nutrient management practice standards to rank fields in terms of phosphorus loss risk and make phosphorus recommendations according to the level of risk to reduce phosphorus losses to surface waters (USDA 2003). Field losses are small compared with fertilizer inputs and harvested outputs (Turner and Rabalais 2003), but even small losses can be large enough to decrease water quality (Smil 2000, Hansen et al. 2002). In 2009, the Iowa Department of Natural Resources listed 50\% of assessed water bodies as impaired under the Clean Water Act (IDNR 2011). Not all phosphorus in rivers comes from soybean fields, but runoff from corn and soybeans contributes the highest total phosphorus runoff $(0.57 \mathrm{~kg}$ of phosphorus per ha per year) compared with other land uses in the Mississippi Basin (Turner and Rabalais 2003). 


\section{Buenos Aires}

Similar to Mato Grosso, the increase in planted soybeans has been rapid and recent in Argentina. Production increased more than fourfold between 1996 and 2007, and soybeans now account for $51 \%$ of the national cropped area (García and Salvagiotti 2009). Similar to Iowa, Buenos Aires has no soils with high phosphorus-binding capacity and is instead dominated by Mollisols and Alfisols (table 2). In contrast to that in both Iowa and Mato Grosso, agricultural intensification in Buenos Aires has been accompanied by only limited phosphorus inputs. We estimate that soybean farms in Buenos Aires fertilize with only $6 \mathrm{~kg}$ of phosphorus per ha per year (see the supplemental material; Fernando O. García, International Plant Nutrition Institute, Argentina, personal communication, March 2011). However, fertilizer inputs to crops rotated with soybean-namely, corn and wheat (García 2001) - have increased dramatically over the past 15 years (see the supplemental material). The yields of all three crops have likewise increased (see the supplemental material). As a result, although the phosphorus budget in Buenos Aires has been mostly negative for the last 15 years, the balances are now approaching neutrality, with a mean of only $0.6 \mathrm{~kg}$ of phosphorus being removed per ha per year (figure 1; supplemental material).

Farmers in Buenos Aires do not currently incur yield penalties for the historic phosphorus deficits, and this may in fact reduce the risk of eutrophication. Although an example of increased turbidity in shallow lakes in areas with intensive agriculture shows a regional relationship between agriculture and water quality (Quiroz et al. 2006), most data suggest that decreased water quality in the region has been associated with industrial or municipal sources (Di Marzio 2005, Pengue 2009) rather than with agriculture, and agriculture has been shown to be extracting rather than creating a surplus of nutrients, including phosphorus (García and Salvagiotti 2009, Pengue 2009, MacDonald et al. 2011). Available phosphorus levels in the soil have been consistently measured as below critical agronomic thresholds (García and Salvagiotti 2009), although with continued increases in fertilization, this may change. Although rapidly increasing fertilizer inputs may shift this trajectory in the future, the phosphorus-related environmental impacts of this production system are currently small (see the supplemental material).

\section{Conclusions}

Our analysis highlights the links and trade-offs between local-scale biophysical properties, management, and both local (eutrophication) and global (depletion of phosphorus reserves) consequences. We have known for millennia that soils play an important role in determining agricultural yields, and we are now paying attention to how soils matter in the control of off-farm agricultural consequences. In these three case studies, regional differences in farming practices and soil phosphorus properties-both total soil phosphorus and phosphorus-binding capacity—alter the trade-offs between local and global environmental costs.
In Iowa, phosphorus losses from agricultural surpluses and farming practices pose local and regional eutrophication risks and, although practitioners have reduced phosphorus surpluses, the legacy of fertilization continues to affect water quality and may continue to do so in the foreseeable future. As is evident in the Mississippi Basin (Jacobson et al. 2011), neutral or even negative phosphorus balances may not be enough to eliminate field phosphorus losses in some regions. Once phosphorus balances approach zero, management that minimizes erosion risk and increases the extent of the riparian zone may be the only way to reduce phosphorus losses. The subsequent treatment of eutrophic surface waters is difficult, expensive, and time intensive (Carpenter et al. 1998, Schindler 2006). The US Department of Agriculture Natural Resources Conservation Service's phosphorus indices integrate regular soil phosphorus testing and management practices with regional soil type and landscape features in an effort to reduce phosphorus pollution at the field scale in the United States (USDA 2003). However, eutrophication of surface waters due to agricultural phosphorus management has become a global problem. Our analysis illustrates the importance of developing region-specific solutions, such as the development of phosphorus indices adapted to local soil types-particularly in rapidly developing countries.

In Buenos Aires, both the local- and the global-scale consequences of soybean agriculture are small relative to those in the other regions. Following a period of phosphorus deficits, phosphorus stocks in soil are now being replenished in Buenos Aires with phosphorus fertilizer additions to the crops planted in rotation with soybeans. Instead of seeing yield decreases from phosphorus deficits or eutrophication from phosphorus surpluses, farmers appear to be approaching neutral phosphorus balances. There is not current evidence of eutrophication from agricultural phosphorus losses in Buenos Aires (Di Marzio 2005, Pengue 2009), but if the trend in fertilizer inputs continues to increase, degradation of water quality may follow and may be difficult to reverse. However, with regular sampling of labile soil phosphorus and near-zero phosphorus balances, the risk of phosphorusinduced eutrophication is likely to remain low.

In contrast to Buenos Aires and Iowa, where managing for phosphorus at the local scale means minimizing phosphorus inputs-thereby reducing the rate of global phosphorus depletion-soybean agriculture in Mato Grosso is impossible without high levels of phosphorus inputs. Despite high phosphorus inputs, the abundance of deep soil with high phosphorus-binding capacity makes the eutrophication risk associated with fertilizer phosphorus lower than in other soil types. The Brazil Forest Code, which includes requirements for riparian zone extent on agricultural land, was recently revised, with the requirements for riparian zones decreasing from between 30 and 500 meters $(\mathrm{m}$ ) to between 5 and $100 \mathrm{~m}$ (Tollefson 2012). Although this reduction in riparian extent may not increase phosphorus losses from soils that are well draining and that have high phosphorus-binding capacity, this revision may have consequences for fields draining other soil 
types. Policies requiring intact riparian zones, however-whether they are large or small-are not wasted, particularly in areas with low phosphorus-binding soils or areas prone to overland flow.

Globally, expansion and intensification of agriculture on highly weathered tropical soil is likely in the coming decades (FAO 2009), and the high levels of phosphorus needed to maintain yields in these areas may accelerate concerns about the pressures on finite phosphorus supplies. Twenty years ago, the soil types that dominate in Mato Grosso were considered some of the poorest in the world, unable to sustain long-term crop production; now, soybean farms there are as productive as those in Iowa because of intense fertilizer use (figure 2). Rapid increases in phosphorus consumption driven by continued expansion of intensive agriculture on these soils with high phosphorus-binding capacity may reduce the number of years of minable rock phosphate remaining. Long before depletion becomes a concern, however, the concentration of phosphorus reserves in only a few countries and the potential for political events to drive the price of fertilizer may have economic ramifications for farmers in this region (Elser and Bennett 2011).

Taking a step further back, this analysis also serves as an example of the complicated trade-offs associated with expanding and intensifying-while reducing the impact of - global agriculture. More than 38\% of Earth's terrestrial surface is in agricultural production-by far the largest global land use (Foley et al. 2011). Much of the land not in production is desert, tundra, or tropical forest. In the same way that we are running out of space, we are pushing up against other planetary boundaries, including agricultural alteration of the phosphorus and nitrogen cycles to an extent that may lead to nonlinear shifts in the global environment (Rockström et al. 2009). Were we, as a global society, trying to optimize only decreasing phosphorus pollution from agriculture, we might recommend that agricultural expansion focus on tropical areas such as Mato Grosso, where nutrient pollution is unlikely despite large fertilizer inputs. Tropical deforestation for agriculture, however, is a large source of greenhouse gas emissions and is a serious threat to biodiversity and other ecosystem services (Foley et al. 2011). The trade-offs are myriad, and there is no single solution.

Society faces a dilemma: We must satisfy the demands for animal feed, food, and biofuels of the nine billion people that will soon inhabit this planet while simultaneously minimizing environmental degradation and conserving finite natural resources (FAO 2009, Foley et al. 2011). We emphasize through this example that the conversation about

minimizing the impact of agriculture must consider the links between local and global environmental problems and solutions.

\section{Acknowledgments}

We thank Martha Downs, Heather Leslie, Kate Smith, Alan Townsend, and Peter Vitousek for helpful feedback on earlier drafts of the manuscript. We also thank Fernando García, Laureano Gherardi, and Osvaldo Sala for helpful discussions about farming practices in Argentina. SP is supported by the Andrew Mellon Foundation, and CN and SHR's work in Mato Grosso was funded by National Science Foundation grant no. NSF-DEB-0640661 and through collaboration with the Instituto de Pesquisa Ambiental da Amazonia. SP, EMB, and MES also thank the Aspen Global Change Institute for hosting the conference that stimulated their thinking on this topic.

\section{References cited}

Ahamed S, Balk D, Flor R, Levy M, Palm C, Sanchez P, Storeygard A, Wood S. 2006. Soil Functional Capacity Classification System Map of the World. HarvestChoice Labs. (9 October 2012; http://harvestchoice.org/ publications/soil-functional-capacity-classification-map-world)

Billen G, Garnier J, Némery J, Sebilo M, Sferratore A, Barles S, Benoit P, Benoit M. 2007. A long-term view of nutrient transfers through the Seine River continuum. Science of the Total Environment 375: 80-97.

Carpenter SR, Bennett EM. 2011. Reconsideration of the planetary boundary for phosphorus. Environmental Research Letters 6 (art. 014009). doi:10.1088/1748-9326/6/1/014009

Carpenter SR, Caraco NF, Correll DL, Howarth RW, Sharpley AN, Smith VH. 1998. Nonpoint pollution of surface waters with phosphorus and nitrogen. Ecological Applications 8: 559-568. 
Childers DL, Corman J, Edwards M, Elser JJ. 2011. Sustainability challenges of phosphorus and food: Solutions from closing the human phosphorus cycle. BioScience 61: 117-124.

Daberkow S, Huang W. 2006. Nutrient management. Pages 117-123 in Weibe KD, Gollehon NR, eds. Agricultural Resources and Environmental Indicators, 2006 ed. US Department of Agriculture Economic Research Service. Electronic Information Bulletin no. 16.

Daoji L, Daler D. 2004. Ocean pollution from land-based sources: East China Sea, China. Ambio 33: 107-113.

Di Marzio WD. 2005. Evaluación de la ecotoxidad de efluentes industriales y municipales. Revista de Ingeniería Sanitaria y Ambiantal-AIDIS 82: 88-93.

Elser J, Bennett E[M]. 2011. Phosphorus cycle: A broken biogeochemical cycle. Nature 478: 29-31.

[FAO] Food and Agriculture Organization of the United Nations. 2009. How to Feed the World in 2050. FAO.

Foley JA, et al. 2011. Solutions for a cultivated planet. Nature 478: 337-342.

Galford GL, Melillo J, Mustard JF, Cerri CEP, Cerri CC. 2010. The Amazon frontier of land-use change: Croplands and consequences for greenhouse gas emissions. Earth Interactions 14. doi:10.1175/2010EI327.1

García F[O]. 2001. Phosphorus balance in the Argentinean Pampas. Better Crops International 15: 22-24.

García FO, Salvagiotti F. 2009. Nutrient use efficiency of cropping systems in the southern cone of Latin America. Pages 35-46 in García F[O], Espinosa J, eds. Nutrient Use Efficiency. International Plant Nutrition Institute. (10 October 2012; www.ipni.net/article/IPNI-3055)

Hansen NC, Daniel TC, Sharpley AN, Lemunyon JL. 2002. The fate and transport of phosphorus in agricultural systems. Journal of Soil and Water Conservation 57: 408-417.

Hayhoe SJ, Neill C, Porder S, McHorney R, Lefebvre P, Coe MT, Elsenbeer H, Krusche AV. 2011. Conversion to soy on the Amazonian agricultural frontier increases streamflow without affecting stormflow dynamics. Global Change Biology 17: 1821-1833.

Heffer P. 2009. Assessment of Fertilizer Use by Crop at the Global Level: 2007/07-2007/08. International Fertilizer Industry Association.

[IBGE] Instituto Brasileiro de Geografia e Estatística. 2011. Levantamento Sistemático da Produção Agrícola. IBGE. (10 October 2012; www.ibge. gov.br/home/estatistica/indicadores/agropecuaria/lspa)

[IDNR] Iowa Department of Natural Resources. 2011. The Final 2010 Iowa List of Section 303(d) Impaired Waters. Iowa Geological and Water Survey, Environmental Services Division, IDNR.

Jacobson LM, David MB, Drinkwater LE. 2011. A spatial analysis of phosphorus in the Mississippi River Basin. Journal of Environmental Quality 40: 931-941.

MacDonald GK, Bennett EM, Potter PA, Ramankutty N. 2011. Agronomic phosphorus imbalances across the world's croplands. Proceedings of the National Academy of Sciences 108: 3086-3091.

Morton DC, DeFries RS, Shimabukuro YE, Anderson LO, Arai E, EspiritoSanto FdB, Freitas R, Morisette J. 2006. Cropland expansion changes deforestation dynamics in the southern Brazilian Amazon. Proceedings of the National Academy of Sciences 103: 14637-14641.

Nepstad DC, Stickler CM, Almeida OT. 2006. Globalization of the Amazon soy and beef industries: Opportunities for conservation. Conservation Biology 20: 1595-1603.

Padgitt M. 1994. Crop rotations. Pages $143-150$ in Anderson M, ed. Agricultural Resources and Environmental Indicators, 1994. US Department of Agriculture Economic Research Service. Agricultural Handbook no. 705.

Pengue WA. 2009. Cuestiones económico-ambientales de las transformaciones agrícolas en las Pampas. Problemas del Desarrollo: Revista Latinoamericana de Economía 40: 138-161.

Quirós R, Boveri MB, Petracci CA, Rennella AM, Rosso JJ, Sosnovsky A, von Bernard HT. 2006. The effects of the Pampa wetlands agriculturization on shallow lakes eutrophication. Pages 1-16 in Tundisi JG, Matsumura-Tundisi T, Sidagis Galli C, eds. Eutrofização na América do Sul: Causas, conseqüências e tecnologias de gerenciamento e controle. Instituto International de Ecologia, Instituto Internacional de Ecologia e Gerenciamento Ambiental, Academia Brasileira de Ciências, Conselho Nacional de Desenvolvimento Científico e Tecnológico, InterAcademy Panel on International Issues, InterAmerican Netword of Academies of Sciences.

Ribaudo M, Gollehon N. 2006. Animal agriculture and the environment. Pages 124-133 in Weibe KD, Gollehon NR, eds. Agricultural Resources and Environmental Indicators, 2006 ed. US Department of Agriculture Economic Research Service. Electronic Information Bulletin no. 16.

Rockström J, et al. 2009. Planetary boundaries: Exploring the safe operating space for humanity. Ecology and Society 14 (art. 32).

Sanchez PA. 1976. Properties and Management of Tropical Soils. Wiley.

Schindler DW. 2006. Recent advances in the understanding and management of eutrophication. Limnology and Oceanography 51: 356-363.

Smil V. 2000. Phosphorus in the environment: Natural flows and human interferences. Annual Review of Energy and the Environment 25: 53-88.

Tilman D, Fargione J, Wolff B, D'Antonio C, Dobson A, Howarth R, Schindler D, Schlesinger WH, Simberloff D, Swackhamer D. 2001. Forecasting agriculturally driven global environmental change. Science 292: 281-284.

Tollefson J. 2012. President prunes forest reforms. Nature 486. (10 October 2012; www.nature.com/news/president-prunes-forest-reforms-1.10772) doi:10.1038/486013a

Turner RE, Rabalais NN. 2003. Linking landscape and water quality in the Mississippi River basin for 200 years. BioScience 53: 563-572.

[USDA] US Department of Agriculture. 2003. Summary of Phosphorus Indices. USDA Agricultural Research Service. (10 October 2012; www.ars.usda.gov/sp2UserFiles/Place/19020500/PhosphorousImages/ Summary_Pindices.pdf)

2010a. Economic Research Service: Briefing Rooms: Soybeans and Oil Crops. USDA. (5 November 2012; http://www.ers.usda.gov/topics/ crops/soybeans-oil-crops.aspx)

-2010b. Fertilizer Use and Price. Data Sets: United States Department of Agriculture: Economic Research Service. (5 November 2012; http:// www.ers.usda.gov/data-products/fertilizer-use-and-price.asp x)

- 2011. Oil Crops Yearbook (89002). USDA Economics, Statistics, and Market Information System. (10 October 2012; http://usda.mannlib. cornell.edu/MannUsda/viewDocumentInfo.do?documentID=1290)

Villalba G, Liu Y, Schroder H, Ayres RU. 2008. Global phosphorus flows in the industrial economy from a production perspective. Journal of Industrial Ecology 12: 557-569.

Walker TW, Syers JK. 1976. Fate of phosphorus during pedogenesis. Geoderma 15: 1-19.

Whalen JK, Chang C. 2001. Phosphorus accumulation in cultivated soils from long-term annual applications of cattle feedlot manure. Journal of Environmental Quality 30: 229-237.

Zhang H, Schroder JL, Fuhrman JK, Basta NT, Storm DE, Payton ME. 2005. Path and multiple regression analyses of phosphorus sorption capacity. Soil Science Society of America Journal 69: 96-106.

Shelby H. Riskin (shelby_riskin@brown.edu) recently finished her PhD, studying the effects of tropical land-use change on soil and water biogeochemistry in a joint program between Brown University, in Providence, Rhode Island, and the Marine Biological Laboratory, in Woods Hole, Massachusetts. Stephen Porder is an assistant professor of ecology at Brown University, in Providence, Rhode Island; his work is focused on the biogeochemistry of tropical forests and the environmental consequences of land-use change in the tropics. Meagan E. Schipanski is a postdoctoral researcher in crop and soil science at Pennsylvania State University, in State College; she applies concepts from ecology to understand plant-soil interactions in agricultural systems. Elena M. Bennett is an assistant professor in the Department of Natural Resource Sciences and in the McGill School of Environment at McGill University, in Montreal, Canada, where she focuses on ecosystem services and how they are managed. Christopher Neill is a senior scientist at the Ecosystems Center of the Marine Biological Laboratory, in Woods Hole, Massachusetts, who studies how land-use change alters ecosystems in the Brazilian Amazon. 